NBER WORKING PAPER SERIES

\title{
IN A WORLD WITHOUT BORDERS: \\ THE IMPACT OF TAXES ON INTERNET COMMERCE
}

\author{
Austan Goolsbee \\ Working Paper 6863 \\ http://www.nber.org/papers/w6863

\section{NATIONAL BUREAU OF ECONOMIC RESEARCH \\ 1050 Massachusetts Avenue \\ Cambridge, MA 02138 \\ December 1998}

I wish to thank David Gross, James Hines, Pete Klenow, Steve Levitt, Casey Mulligan, Joel Slemrod, Michelle White, Alwyn Young, Jonathan Zittrain and seminar participants at the University of Chicago and the University of Michigan for helpful discussions. The views expressed here are those of the author and do not reflect those of the National Bureau of Economic Research.

- 1998 by Austan Goolsbee. All rights reserved. Short sections of text, not to exceed two paragraphs, may be quoted without explicit permission provided that full credit, including ${ }^{\bullet}$ notice, is given to the source. 
In a World Without Borders:

The Impact of Taxes on Internet Commerce

Austan Goolsbee

NBER Working Paper No. 6863

December 1998

\title{
ABSTRACT
}

The rapid rise in sales over the Internet has generated debate over the taxation of such transactions since the buyers usually pay no sales tax. This paper uses new data on the purchase decisions of approximately 25,000 online users to examine the effects that local sales taxes have on Internet commerce. The results show that, controlling for many observable characteristics, people who live in locations with high sales taxes are significantly more likely to buy things over the Internet. The estimated tax responsiveness of both participation and spending are large and resemble the tax effects found in previous research on retail sales in geographic border areas. The results are quite robust; the tax sensitivity is clear nationally, within regions, within states, and even within metropolitan areas. Further results suggest that the tax effect cannot be explained by unobserved heterogeneity across cities. The magnitudes in the paper suggest that to apply existing sales taxes to Internet commerce would reduce the number of online buyers by $25 \%$ and spending by more than $30 \%$ with some specifications suggesting even larger effects.

\author{
Austan Goolsbee \\ Graduate School of Business \\ University of Chicago \\ 1101 E. 58th Street \\ Chicago, IL 60637 \\ and NBER \\ goolsbee@gsb.uchicago.edu
}




\section{Introduction}

The extraordinary growth of the Internet in the last few years, from fewer than 5 million users in 1993 to 62 million in 1997 (Department of Commerce, 1998), has led some to speak of the birth of a "world without borders," where free communication, competitive markets, and extensive comparison shopping are a matter of course (see The Economist, 1997a; Hof, 1998; Pouliot, 1998). This apparent lack of geography in cyberspace, however, has raised some difficult issues regarding government policy toward the "new" economy, particularly regarding tax policy.

The sales of products and services over the Internet have grown even faster than the overall use of the Internet; data from Jupiter Communications suggests online sales have been rising about $300 \%$ per year (Krantz, 1998) and are expected to continue growing at tremendous rates. Forrester Research predicts that, by the year 2000, total online sales will exceed \$200 billion. At the extreme, Nicholas Negroponte, founder of the MIT media laboratory has predicted that such commerce may exceed $\$ 1$ trillion by 2000. Although online transactions currently make up only a very small fraction of total retail sales, predictions such as these have caused state policy makers to become highly concerned with the fact that most online transactions pay no sales tax. ${ }^{1}$ If these growth predictions are anywhere close to accurate, tax policy toward Internet commerce promises to have serious consequences for future state tax policy since the sales tax makes up the largest single component of state revenues.

Economists have long argued that consumer sensitivity to tax rates will be larger for people living along geographic borders or in an open economy, more generally, where the costs of arbitraging tax rates across locations are low, and that this can have important implications for the

\footnotetext{
${ }^{1}$ In general, Internet sales are treated the same as mail-order sales. No sales tax is collected from companies that have no presence (known as nexus) in the state. Although sales tax is not collected, technically states apply a use tax which requires consumers to pay the equivalent of the state sales tax on their mail-order and Internet purchases. The supreme court has ruled, however, that under existing law, an out-of-state vendor without nexus in a state cannot be required to collect the use tax for that state even if the customer lives there (National Bellas Hess, 386 U.S. 753, 1967; Quill, 504 U.S. 298, 1992). This has meant that use taxes have rather extreme compliance problems and are little known by most consumers (see Trandel, 1992). Enforcement of the use tax has only been effective for goods like automobiles that must be registered in the state of use.
} 
setting of tax policy. ${ }^{2}$ Empirical work on the responsiveness in border communities to taxes and other such policies has tended to bear out these predictions by finding large elasticities in such locations. $^{3}$

Against this backdrop, then, perhaps the key issue that the Internet poses for tax policy is not so much its potential to create a world without borders but rather to create a world of only borders-a world in which everyone is as responsive to local taxation as people who live on geographic borders. With that perspective, it is clear why state lawmakers and some in the popular press have decried "the disappearing taxpayer" and have called for reform (see The Economist, 1997a; 1997b). State Tax Notes has declared the issue of taxes and electronic commerce "the hottest topic in multistate taxation" (Sheppard, 1998) and the National Governors Association itself has called for a uniform tax on all Internet and mail-order sales. They argue that this would protect their revenue base and protect "Main Street" businesses.

On the other hand, there is also serious opposition to taxes on the Internet. The opponents have argued that introducing taxes now might seriously impede the Internet's growth at a critical stage of early development (see, for example, Stephenson and Zeisser, 1998). The recent passage of the Internet Tax Freedom Act is certainly one manifestation of this view although in its final form it does not prohibit uniform sales taxes. ${ }^{5}$ Other opponents have argued that compliance with the thousands of local tax rates, or even monitoring those rates, would be unduly burdensome on out-of-state companies, especially for sellers of information goods that are delivered online and often do not even have a customer's mailing address.

\footnotetext{
${ }^{2}$ Such theoretical discussions can be found in Gordon (1983), Mintz and Tulkens (1986), Braid (1987), Kanbur and Keen (1993), Trandel (1992; 1994) and Gordon and Neilsen (1997).

3 Empirical work on sales taxes and excise taxes in border areas can be found in Mikesell (1970), Fox (1986), Walsh and Jones (1988), or Rappaport (1994). Holmes (1998) gives similar evidence on the effects of right-to-work laws in border regions.

4 To actually impose such a tax, however, would currently violate the Interstate Commerce Clause of the constitution and would require a specific federal law permitting states to require out-of-state companies without nexus in a state, nevertheless, to collect use taxes for that state (see footnote 1). Fox and Murray (1997) give a good discussion of the issues.

${ }^{5}$ The ITFA establishes a moratorium on new taxes but applying a sales tax to Internet sales would not be considered a new tax so long as it applies to retail and out-of-state mail-order sales at the same time.
} 
Despite ongoing policy interest and despite the potential relevance to the broader field of open economy tax policy, there has been little empirical work on the impact of tax policy on Internet commerce. Most economic work on the Internet has focused on more basic issues such as pricing and access. ${ }^{6}$ Existing discussions of taxes and Internet commerce have either centered on legal and practical issues (see, for example, Horner and Owens, 1996; Bourgeois and Blanchette, 1997) or else on the conceptual basis for Internet tax policy (Fox and Murray, 1997; McLure, 1997). Nor can we take lessons from previous research on mail-order sales which face exactly the same issues. There is virtually no empirical work on that subject, either. Indeed past work that has advocated administering taxes on out-of-state mail-order sales, has explicitly assumed that there are no behavioral impacts (ACIR, 1986).

In this paper, I attempt to provide a rigorous empirical foundation for discussions of Internet commerce by estimating how such commerce responds to local tax rates. To do so, I turn to a major recent survey of the online purchase patterns of approximately 25,000 people with access to the Internet in more than 350 cities and metropolitan areas and match these data to the tax rates in those communities. The results show that Internet sales are highly sensitive to local taxation. This is true nationally, within regions, within states, and even within metropolitan areas. Controlling for individual characteristics, people who live in high sales tax locations are significantly more likely to buy over the Internet and I can show that this is unlikely to result from unobserved heterogeneity across locations. The paper also uses data on computers to compare the apparent tax responsiveness of both Internet and mail-order sales and finds similar effects for both of the "non-taxed" channels.

The estimated tax elasticities of Internet commerce with respect to local taxation are quite large and thus resemble the elasticities found in previous sales tax studies of geographical border areas. In policy terms, the results suggest that to apply existing sales taxes to Internet purchases

\footnotetext{
6 Examples of such work include Mackie-Mason and Varian (1995), Downes and Greenstein (1998), and the papers in McKnight and Bailey (1995).
} 
would reduce the number of online buyers by $20-25 \%$ and spending by $25-30 \%$. The large elasticities estimated here raise important questions about long-run tax policy toward Internet commerce.

The paper proceeds as follows. Section II describes the data used in the paper and the general approach. Section III presents the basic evidence that taxes impact online buying decisions and shows it to be highly robust. Section IV examines the mail-order/Internet distinction for the case of computer purchases. Section V gives policy simulations of proposed taxes on Internet commerce as well as some discussion of the longer-run role of sales taxes. Section VI concludes.

\section{Data and Specification}

A. Data

A major problem with doing empirical work on Internet commerce has been data. Aggregate data is not very useful. Observing that Internet sales are high in places with high taxes may just indicate that places with high taxes have higher incomes, higher computer ownership, higher education, or any number of factors that are correlated with online buying. Individual data is extremely important but few consumer surveys even ask about the Internet and if they do, it is hard to get sufficient sample sizes. In any random sample of the population, less than half the respondents are likely to have computers, of those, only a fraction have Internet access and only a small share of those have ever bought something online. To examine the response of such purchases to local taxation then requires further dividing up the Internet shoppers by geographic location. It is easy to see why this will tend to yield small samples.

In this paper, I turn to an extensive private survey conducted in late 1997 for Forrester Inc., a market research company in Cambridge, Massachusetts. The survey was conducted by the NPD group and is meant to provide a nationally representative portrait of the computer and technology decisions of more than 110,000 consumers. The survey includes detailed information 
about various demographic characteristics such as income, age, gender, education, as well as the state and metropolitan area of residence. ${ }^{7}$ The information covers the ownership of computers, as well. About $45 \%$ of the respondents had computers at the time of the survey. Those owners were then asked whether they had online access and if so, how often they used it and were asked for their online buying history. In total this yields a sample of about 25,000 online users, sixteen percent of whom report having purchased something online.

For each individual that has bought something online, the survey asks how much they have spent (in four groupings: $\$ 0-25, \$ 25-100, \$ 100-500$, and $\$ 500+$ ) for different types of goods such as books, software, or computers. I use the Forrester imputed values for each spending category and sum across the types of goods to approximate the total amount spent online. Using this measure, the average amount spent, conditional on buying, is $\$ 322$. This is similar to existing estimates of average online spending such as Krantz (1998). Although the analysis will be done at the individual level, for expositional purposes, figure 1 shows the share of Internet users that have purchased something online in each state. There is decided variation across locations.

Matching the purchase data to local sales tax rates requires making some assumptions because the data do not give the actual town name of the respondent. Even if it did, there are as many as 6400 different sales tax rates across the United States (see Rappaport, 1994) and information on them is not kept by the federal government and must be collected at the state and local level.

I assume, first, that any one living in the primary state of the metropolitan area actually lives in the primary city itself. In other words, I assume that a person in the Chicago metropolitan area who lives in Illinois lives in the city of Chicago. This prevents me from distinguishing between city and suburb within the same state, but is necessary given the nature of the data. Since, when they differ, the tax rates will almost always be lower in the suburbs, this error in

\footnotetext{
7 The metropolitan areas are actually defined as the television market the respondent lives in. These are generally larger than the corresponding SMSA. San Francisco, for example, includes the entire bay area.
} 
measurement will tend to bias the estimated tax elasticities downward.

For practical purposes, I assume, next, that anyone living outside the primary state resides in the physically closest county to the main city (measured using Rand McNally, 1997). If that state is one that applies both city and county rates, such as Oklahoma, I assume that they live in the largest city in that closest county.

In total, this yields 351 different city-state locations. The tax rates for most of these 351 locations were then compiled individually either from direct conversation with the department of revenue in the state or from documents on the department's website. For states without centralized information, I contacted a local chamber of commerce in the city or county. Specific local information was not necessary for some of the states since several have constant statewide tax rates and four have no sales tax at all (Montana, New Hampshire, Delaware, and Oregon). The average sales tax rate in a state (weighted by population) is shown in figure 2.

Table 1 gives summary statistics of the sample of people with online access and then divided according to whether or not they have ever purchased something online. The two are not very different in most measures although online buyers appear to be slightly better educated than other online users, are somewhat more likely to be female, and so on.

\section{B. Model and Specification}

The idea of the paper is simple. An individual choosing whether to buy a good at a store versus online will compare the relative prices. Assuming that he avoids paying use tax on the online transaction and that local sales taxes do not affect local retail prices (i.e., elastic local supply), the individual will be more likely to buy online the greater is the relative price ratio

$$
\frac{P_{S}(1+t)}{P_{I}},
$$

where the $t$ is the sales tax, $P$ is price and the subscript $S$ indicates in a retail store and $I$ indicates 
an online merchant. ${ }^{8}$ I will follow the common assumption in the literature on sales taxes across regions and assume the relative price, $P_{S} / P_{I}$, is constant across regions. Two comparisons of Internet and retail prices (Goldman Sachs, 1997; Bailey, 1998) suggest that the ratio is close to 1 for many common products so I will assume that for the elasticity calculations.

I will use two related specifications for the individual's choices about Internet commerce each of which will include the tax rate and a number of economic and demographic controls such as income, age, and education. For the probability of having bought something online, I will use a probit model. For the amount that an individual reports having spent online, I will use a Tobit model (censored because a large number of people report no spending).

\section{Results}

The initial results from estimating the probit regression of the $\{0,1\}$ response of having ever bought online (conditional on having Internet access) are presented in column 1 of table 2 . The coefficients listed give the estimated marginal effects of the covariates on the probability of buying online. The mean probability of buying conditional on having online access is estimated to be $20.3 \%$. The explanatory variables other than the sales tax term include income, education, age, race, gender, marital status, and dummies for the presence of children under 18 in the respondent's household, whether the respondent operates their own business, uses a computer at work, or owned a computer in the previous year. The standard errors are corrected for the fact that tax rates do not vary at the individual level but only by city and state.

The results show that the sales tax does appear to have a significant impact on the decision to buy online and has the predicted sign. The magnitude suggests that at the mean of the covariates, raising the sales tax by .01 increases the probability of buying online by about .005 . Since the mean probability of purchase is approximately .20 , the estimated elasticity of online

\footnotetext{
${ }^{8}$ The impact of local taxes on local prices has been examined by Poterba (1996) who finds no effect on pre-tax prices and by Besley and Case (1998) who find that higher taxes actually raise pre-tax prices.
} 
buying with respect to the tax price (one plus the tax rate) is 2.3 . The other coefficients are significant and have predictable signs. Higher income, more education, and using a computer at work make a person more likely to have bought online. Being older, male, or married make a person less likely.

Column 2, presents the Tobit version of the same specification where the dependent variable is the amount the individual has spent online. Again, there is evidence of a significant effect of tax rates on Internet commerce. At the mean, the elasticity of spending with respect to one plus the tax rate is 3.6.

Both of these estimates may suffer from an obvious potential source of bias. They show that, controlling for observables, people who live in high sales tax locations tend to buy more over the Internet. It is clearly possible that places with high levels of "technological sophistication" where people are disproportionately likely to have bought online may primarily be urban areas like New York and San Francisco which also happen to have high sales tax rates, leading to a spurious correlation. In theory, the relationship could even be created by city level policies. If a city raised its sales tax in order to pay for Internet infrastructure to make online use easier, this would certainly make high sales taxes look influential for online buying but for a different reason. I will attempt to deal with potential unobserved heterogeneity bias in a number of ways but it is important to note that the bias need not go in this direction. Other factors may bias the results in the opposite way. The results in table 1, for example, condition on having online access. If the only people with online access in a technologically "backward" locations (that also tend to have low tax rates) are the diehard Internet users who frequently buy, this will bias the coefficient downward.

To deal with the unobserved city characteristics, I first present (columns 3 and 4) the same probit and Tobit regressions but restrict the sample to include only the top 30 metropolitan areas with the idea that these may be more comparable locations and will help eliminate any bias caused from comparison to rural and small town locations. This restriction reduces the sample by more 
than $40 \%$. The coefficients on the sales tax, however, are not significantly different than in the full sample and the point estimates are larger. They still show that taxes appear to have a significant effect on Internet purchases. The elasticities here are 2.9 on buying and 3.4 on spending. Obviously this does not rule out the spurious correlation, but does suggest that whatever the correlation between technological sophistication and tax rates, it must be just as true among the top 30 cities as it is between large metropolitan areas and more rural areas.

Next, in table 3, I use the variation in tax rates across geographic areas to further narrow the comparison groups. Column 1 and 2 include region dummies and asks whether individuals with the same observable characteristics and living in the same region are more likely to buy online in a city with a higher tax rate. In both the probit and Tobit regressions, taxes have a significant impact within regions. The elasticities at the mean are 2.4 and 3.5. Column 3 and 4 include state dummies and ask whether people with the same observables living in the same state are more likely to buy online where the sales tax is higher. Here the coefficients are particularly large and significant suggesting that taxes matter within a given state. The elasticities at the mean are 8.4 and 11.7 .

More importantly, however, columns 5 and 6 then include dummies for the metropolitan area itself and asks whether people with identical observables living in the same metropolitan area but in different states (where sales taxes can differ) are more likely to buy online if their part of town has higher tax rates. Of the 207 metropolitan areas in the sample, 71 have people living across state boundaries. New York, Philadelphia, and Washington D.C. are the most prominent examples but there are many others. The coefficient on local taxation in both specifications remains large and significant. The elasticities at the mean are 3.6 and 4.8 in the two equations. All of the results that follow will include these metropolitan area dummies to give the best controls.

To show these within metropolitan area results more clearly, columns 7 and 8 look at such city level variation in the most prominent metropolitan areas that cross state boundaries and have 
significant sales tax variation. Of the top-30 greater metropolitan areas, there are four with $15 \%$ or more of the population living outside the primary state and also have differences in sales tax rates across the communities of more than half a percentage point. Those four are New York (NY, CT, and NJ), Philadelphia (PA, NJ, and DE), Washington, D.C. (DC, VA, and MD), and Boston (MA, NH, and VT). The results show that people with the same observables living in the metropolitan area but living in the part of town with higher taxes are significantly more likely to buy over the Internet in these four cities. The elasticities are even larger here than in the economy wide specifications. The elasticity of buying is more than 7 and the elasticity of spending is more than 8 .

Taken together, the results in table 3 suggest that at any level of analysis, retail sales taxes do matter for Internet commerce. It may still be true, of course, that these results reflect a correlation between taxes and unobserved variables. These results suggest, however, that such correlation must be just as high or even higher within regions, states, and metropolitan areas. In other words, the correlation between unobserved technological sophistication or Internet infrastructure and the sales tax rate within the New York City area (NY vs. CT, say) must be greater than the correlation between New York City and Bowling Green, Kentucky which has the same tax rate as $\mathrm{CT}$.

In Table 4, I present further evidence on the subject of unobservables. First, column 1 adds the top marginal income tax rate in the state to see if that appears to influence the online buying probability. There is little reason to expect that it should influence online buying. If it seems to matter and reduces the effect of the sales tax, this might cast doubt on the causal interpretation of the sales tax coefficient. The results show, however, that the sales tax coefficient is unchanged (elasticity is still 3.9) and that there is no significant effect of income tax rates.

Next, each respondent with online access reports their frequency of going online. If the tax coefficient in the online purchase regressions arises from unobserved technological sophistication or Internet infrastructure, controlling for online usage should tend to reduce or 
eliminate the tax coefficient on purchasing. Column 2 shows that online use (in days per month) does have a large, significant effect on the probability of buying online. It does not, however, reduce or eliminate the tax coefficient. That coefficient remains large and significant with an elasticity of buying of almost 4.

On top of that, column 3 deals with the unobserved heterogeneity point directly by examining the respondent's online frequency of use as the dependent variable and asks whether use is higher in locations where there are high taxes. There is no reason to expect that high local retail sales taxes should have an effect on the frequency of online use (as opposed to online purchases). Any positive relationship here would strongly suggest that tax rates are correlated with technological sophistication, Internet infrastructure, or the like. The results, however, show no such effect. The coefficient on taxes is insignificant and extremely small. People in a city at the lowest decile of sales tax (.04725) use the Internet approximately .003 days per month less frequently than people in the top decile of sales tax (.08). The mean frequency of use is 16.7 days per month so the effect is really quite small. Even if the coefficient were the highest value in the $95 \%$ confidence interval, the increase would still be less than half a day per month. These results suggest that people in high tax locations are no more likely to use the Internet, only to buy things over the Internet (even controlling for how much they use the Internet).

Column 4 examines how many computers the respondent reports having ever owned. Again, if there is unobserved technological sophistication correlated with tax rates, people in places with high rates will buy more over the Internet but are also likely to have owned more computers over time than people in places with low rates. The results show, however, that the point estimate is very small, not significant and the sign is actually negative. The average person with online access has owned 1.97 computers in their lifetime. Moving from the bottom decile of tax rates to the top decile reduces the number of computers at the mean by .03 .

Next, column 5 uses the respondents self evaluation from one to ten of the statement "I like technology." This is an arbitrary ranking but, again, there is no evidence that people living in 
high tax locations like technology more than people in low tax locations. The point estimate is negative though small and insignificant.

The evidence, then, is somewhat robust that Internet commerce is sensitive to local tax rates and there is little evidence that the effect is spurious. The elasticity of online purchases when including the controls for metropolitan area are comfortably above 3 with the elasticity of spending of almost 4. Some specifications suggest even larger effects. These elasticities are quite close to similar elasticities estimated for the tax responsiveness of sales in border communities and open economies in the research mentioned above. The elasticities there are often close to 5 or 6. Implicit in the discussion has been the view that consumers are deciding between retail purchases and Internet purchases. If Internet purchases are instead coming out of mail-order sales, the implications for policy making may be different. Since mail-order faces no sales tax, however, it is difficult to see why Internet sales would be higher in places with high sales taxes. For one particular good, however, I am able to consider the mail-order context simultaneously.

\section{Retail, Mail-Order, and the Internet.}

The treatment of Internet sales is, as stated previously, exactly the same as that of mailorder companies so it is natural to wonder why states have expended so much effort recently to allow the taxation of Internet commerce instead of devoting considerably more attention to the currently much larger sales of mail-order. According to the Census of Retail, mail-order company sales amounted to $\$ 48.8$ billion in 1997 and this is likely to be an under-estimate for reasons described in ACIR (1986). Such a number well exceeds the current size of Internet purchases.

There are likely to be two reasons for this behavior. The first is that, in some sense, the battle over mail-order sales has already been lost. The supreme court has ruled that states cannot require out-of-state companies to collect use tax without congressional legislation permitting it. Major proposals to pass such legislation in the 1980s such as ACIR (1986) were defeated. The mail-order business is now well established and has a major lobby in its own right. In this sense 
the Internet is more pressing precisely because it is not yet well established.

A second reason the states may be less concerned with mail-order, however, is that the growth of mail-order relative to retail sales has slowed considerably in recent years. The mailorder share of total retail sales, as reported in the Monthly Retail Sales, grew at an annual rate of almost 9\% from 1985 to 1992 (Bureau of the Census, various). ACIR (1986) suggests that this growth followed years of growth in the late 1970s and early 1980s of comparable annual rates. From 1992 to 1998, however, the growth rate has been only about $0.5 \%$ per year. Mail-order's share of sales seems to have reached a plateau, lessening the urgency on the part of departments of revenue around the country. Certainly Internet sales will also slow down eventually but the question is after how long? With growth rates of $300 \%$ per year and the predictions of continued massive growth, the Internet may easily become significantly more important that mail-order is now. That has made it a primary area of concern.

A key issue in this context is whether the tax sensitivity of Internet commerce is similar to that of mail-order sales. Unfortunately, to my knowledge, there is no empirical work examining this question. This is likely due to a lack of data. Using the Forrester data, however, I can relate the tax sensitivities of mail-order and Internet sales for at least one product type. In addition to the online sales information used above, the Forrester data provide detailed information about computer purchases (this is the data used in Goolsbee and Klenow, 1998) and this information includes where computer owners bought their machines. The choices include a variety of types of retail establishments, "online," and "direct from the manufacturer." In 1997, there were almost 40,000 computer owners in the sample. I classify "direct from the manufacturer" as mail-order though that may include some Internet purchases in recent years. With this classification, 79\% of people bought their current computer in a store, about $19 \%$ through mail-order, and almost $2 \%$ online.

Using these data, I ask whether, conditional on having a computer, individuals more likely to have bought either online or through mail-order in places where there are high sales taxes. 
This is, in a sense, a two-step decision where at the top level the individual decides whether to buy a computer and next decides where to buy the computer. To estimate this lower level decision, I use a logit model where the dependent variable is zero if the computer was bought at a retail store and one if it was bought online or through mail-order. The explanatory variables are the same as in the specifications above and they include the metropolitan area dummies. The results listed in column 1 of Table 5 show that the coefficient on local taxation is positive and significant, suggesting that people with a computer and the same observables who live in the same metropolitan area are more likely to have bought their computer in a retail store the lower is the local tax rate. The magnitude of the coefficient suggests that lowering the sales tax by .05 (an exercise that will be of particular interest in the next section) would lower the probability of buying "remotely" through mail-order or the Internet from .222 to .178, a decrease of almost $20 \%$.

In columns $2 \mathrm{a}$ and $2 \mathrm{~b}$, I estimate a multinomial logit model that separates the mail-order and Internet buyers. Here the baseline is buying from a retail store and the individual can choose either mail-order or online purchase as an alternative. I restrict the coefficients on the non-tax terms to be the same for mail-order and for online sales to make the tax coefficients comparable but the results were the same allowing the covariates to impact the choices differently. Although the number of Internet purchasers is much smaller and thus the standard error is larger, the coefficients on mail-order and online purchases are both large and positive and they are not significantly different. The point estimates of the Internet are even larger than on mail-order. At existing tax rates, the mean probability of having bought in a store is .817 , through mail-order is .169 , and online is .014 . Lowering the sales tax by .05 raises the retail probability to .858 , lowers the mail-order probability by more than $20 \%$ to .133 and the online probability more than $35 \%$ to .009. Although this is evidence only on one product, it does suggest that similar tax considerations are at work with mail-order sales as they are with online sales and raises the issue of whether applying taxes to the Internet would merely shift sales toward mail-order purchases. 


\section{Policy Implications}

\section{A. Impacts of major proposals}

At this point, given the estimates presented in the previous section, it is natural to ask what would happen to Internet commerce if the United States were to start taxing it effectively such as having the firms collect the tax. The two most relevant existing policy proposals are the proposal by the NGA to apply a consistent $5 \%$ rate to all Internet and mail-order sales and the more general proposal to let each local area simply apply existing sales taxes to all Internet commerce. ${ }^{9}$ In general this latter policy implies a somewhat higher tax rate since the average tax rate in the sample, when weighted by population, is $6.33 \%$.

The results above use the sales tax on retail sales to explain Internet sales. To calculate the impact of applying sales taxes to the Internet is a slightly different question. I have been interpreting the tax sensitivity of online commerce as being caused by the price differential between it and retail. In that sense, applying a 5\% tax to Internet sales is equivalent to reducing the tax on retail sales by $5 \%$. All that matters is the relative tax treatment.

Consider, then, the two proposals (applying a 5\% rate and applying existing rates). On average, as would be expected given the large elasticities, applying a sales tax to Internet commerce significantly reduces online commerce. If a five percent tax rate were applied to online sales (calculated here as reducing the retail sales tax by 5\%), the number of online customers would be $18 \%$ lower (using the specifications that include metropolitan area dummies) and total sales $23 \%$ smaller. The alternative proposal of applying existing tax rates to commerce would eliminate even more Internet commerce. It would reduce the number of buyers by $24 \%$ and spending by $30 \%$. Responses in some of the specifications were even larger.

Any such calculation is, necessarily, partial equilibrium in nature. It is identified off of the cross-sectional variation in tax rates which may not be the same as the effect generated by an

\footnotetext{
${ }^{9}$ In practice, obviously, use taxes already exist so the issue would be the same as applying an enforceable use tax.
} 
aggregate shock to the tax rate in all locations. An upward sloping supply curve of Internet firms might lead to price changes, for example, which blunt the effects of tax changes on quantities (see Goolsbee, 1998 for a discussion in the investment context). That said, the results do suggest that Internet commerce is particularly sensitive to local taxation.

Since the Internet is such a small part of existing retail sales, however, the results document that the taxation of Internet commerce matters much more for the Internet commerce than it does for tax revenue at the present time. Even a 30\% drop in Internet sales has a very small impact on retail sales or total sales tax revenue in a state. One result of that fact is that protecting Internet commerce from taxation, for whatever reason, is unlikely to be very costly though that will change if the Internet continues growing at current rates.

\section{B. Long-run Policymaking}

Even for current tax policy, however, the results pose a paradox for taxes and the Internet. From one perspective, there is clear evidence that a price differential is generating shifting across distribution channels which will tend to generate a deadweight loss. In the spirit of Cortlett and Hague's (1954) conclusion that we should tax substitutes similarly, eliminating the differential taxation would seem to be welfare improving (see also the discussion in McLure, 1997). This point has certainly been made about mail-order sales (ACIR, 1986).

At the same time, however, the same large responses suggest that to apply taxes now would reduce Internet commerce substantially and several arguments may weigh against doing so, at least in the short run. ${ }^{10}$ First, as the results on computers demonstrated, mail-order and Internet sales appear to be equally responsive, at least for computers. Given that out-of-state mail-order sales are generally untaxed, it is important to find out whether Internet sales would otherwise have been bought through the mail. If they are, applying taxes to the Internet without

\footnotetext{
${ }^{10}$ A more detailed discussion and evaluation of many different arguments for and against taxing Internet commerce is the subject of ongoing research in Goolsbee and Zittrain (1998).
} 
applying taxes to mail-order will reduce consumer welfare without generating any revenue. In the case of computers and probably a number of other goods, this issue is clearly relevant and it highlights the importance of not setting Internet tax policy unilaterally.

Second, there may be serious problems with enforcing a tax on Internet sales. Even if congress decides that states can require out-of-state vendors to collect use tax on sales, the Internet will face a number of problems that mail-order companies do not. Increasingly, for example, Internet sales are information goods such as software that can be directly downloaded with no mailing address. In such a circumstance, calculating the relevant tax rate and enforcing it may be expensive (see The Economist, 1997b).

Finally, there are some externality based stories that may support lower tax rates. If there are network externalities associated with the Internet or there are information uncertainties about using credit cards online, an infant industry protection type argument might suggest a moratorium on taxes until the Internet is better established. The fact that the Internet is currently such a small segment of retail sales means that the revenue cost of providing this protection in the short-run is small. Relatedly, even if maximizing revenue is the only goal of state governments, the existence of network externalities in Internet commerce may suggest that taxes should be low or even negative early on to increase the size of the Internet in the future. Ron Wyden, a co-sponsor of the Internet Tax Freedom Act, seems to have had an argument like this in mind when he explained the need for federal action by saying "the crazy quilt of state and local taxes could do irreparable harm to the Internet, killing the goose that could lay billions of dollars in golden eggs." (Wyden, 1997). In addition, work by Trandel (1992) suggests that having low tax rates in outlying geographic areas can reduce the market power of city retailers and force down markups which improves consumer welfare. This same argument may be true for applying low tax rates for Internet retailers.

\section{Conclusion}


This paper presents an empirical analysis of how local taxation affects individual's decisions to buy things over the Internet. Using an extensive data source of approximately 25,000 people with online access, this paper has shown that such taxes play an influential role in online commerce. Controlling for individual characteristics, people living in places with higher tax rates are significantly more likely to buy things over the Internet. This is true within regions, within states, and even within cities. The effect remains when controlling for individual use of the Internet. People living in high tax locations are no more likely to use the Internet, to have owned several computers, or to like technology than people in low tax cities. The relationship between taxes and Internet sales is, therefore, unlikely to be caused by unobservable correlation between tax rates and unobserved technological sophistication across locations. Using data on computer purchases, the data also suggest that the tax impact on Internet purchases may be somewhat similar to the tax impact on mail-order sales.

The magnitudes on Internet sales are quite large and suggest that applying existing sales taxes to the Internet might reduce the number of online buyers by $25 \%$ and online spending by $30 \%$ or more. Since Internet sales currently make up such a small fraction of total retail sales, however, the revenue loss from not applying such taxes is rather small so the cost of protecting the Internet in the short-run is small. If the growth rate of the Internet continues at current rates, however, this could change.

In total, the results give empirical support to the idea that local taxes can play an important role for individuals living in a "world without borders" and they motivate further empirical work on the role of taxes in an open economy such as the Internet. 


\section{FIGURE 1}

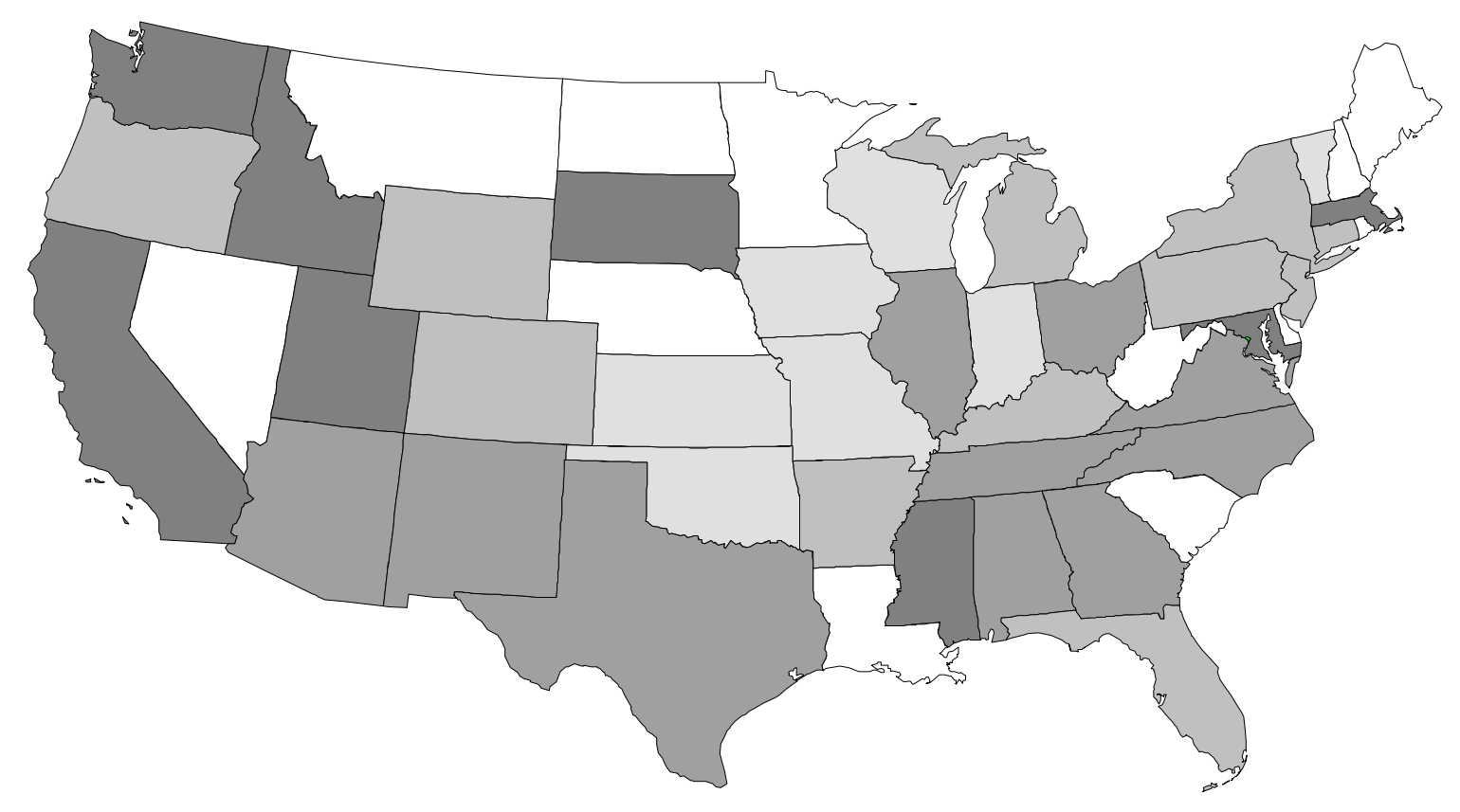

Average Probability of Online Purchase for Internet Users

0.23 to 0.292 (8)

0.213 to 0.23 (10)

0.196 to $0.213(11)$

0.171 to $0.196 \quad$ (7)

0.117 to 0.171 (12) 
FIGURE 2

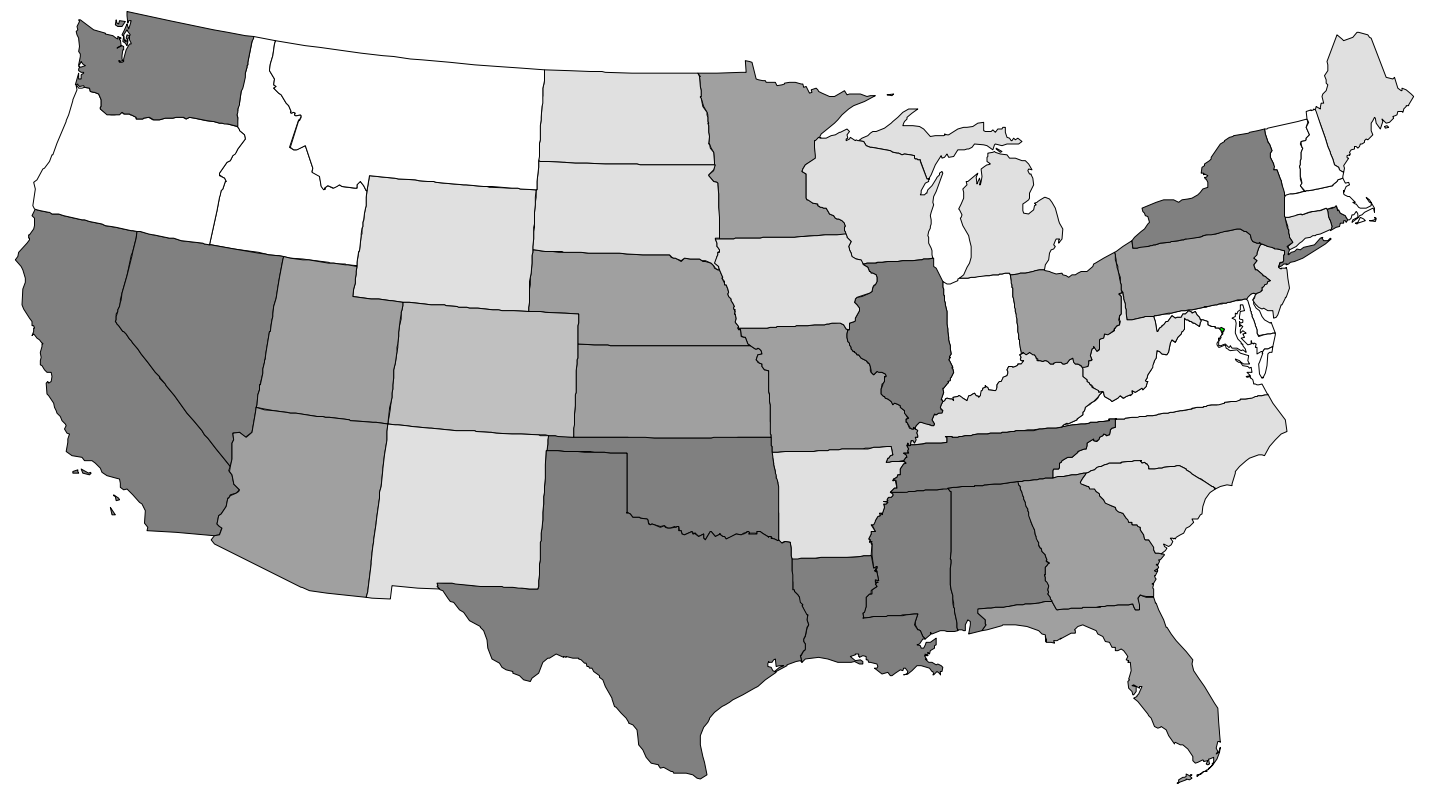

$\begin{gathered}\text { Average Sales Tax Rate } \\ \text { in Percent }\end{gathered}$
$\square 6.9$ to 8.4 (12)
$\square 6$ to 6.9 (10)
$\square 6.1$ to 6.2 (1)
$\square 5.1$ to 6.1 (15)
$\square 0$ to 5.1 (10)


TABLE 1: SUMMARY STATISTICS

\begin{tabular}{|c|c|c|c|}
\hline & All Online Users & Buyers & Non-Buyers \\
\hline $\mathrm{n}$ & 26219 & 5544 & 20675 \\
\hline$(1+t)$ & 1.066 & 1.067 & 1.066 \\
\hline Income & 61.1 & 65.3 & 59.9 \\
\hline & $\begin{array}{c}(41.1) \\
149\end{array}$ & $\begin{array}{l}(42.2) \\
152\end{array}$ & $\begin{array}{c}(40.8) \\
148\end{array}$ \\
\hline Education & $\begin{array}{l}14.9 \\
(2.2)\end{array}$ & $\begin{array}{l}15.2 \\
(2.2)\end{array}$ & $\begin{array}{l}14.8 \\
(2.3)\end{array}$ \\
\hline Age & $\begin{array}{c}40.1 \\
(12.4)\end{array}$ & $\begin{array}{c}39.3 \\
(11.9)\end{array}$ & $\begin{array}{c}40.4 \\
(12.6)\end{array}$ \\
\hline Asian & $\begin{array}{c}.021 \\
(.142)\end{array}$ & $\begin{array}{c}.026 \\
(.159)\end{array}$ & $\begin{array}{c}.019 \\
(.137)\end{array}$ \\
\hline Nonwhite minority & $\begin{array}{l}.145 \\
(.352)\end{array}$ & $\begin{array}{l}.137 \\
. .344)\end{array}$ & $\begin{array}{l}.147 \\
(.354)\end{array}$ \\
\hline Children & $\begin{array}{c}.408 \\
(.491)\end{array}$ & $\begin{array}{c}.360 \\
(.480)\end{array}$ & $\begin{array}{c}.421 \\
(.494)\end{array}$ \\
\hline Single & $\begin{array}{c}.399 \\
(.490)\end{array}$ & $\begin{array}{c}.433 \\
(.496)\end{array}$ & $\begin{array}{c}.390 \\
(.488)\end{array}$ \\
\hline Female & $\begin{array}{c}.556 \\
(.497)\end{array}$ & $\begin{array}{c}.648 \\
(.478)\end{array}$ & $\begin{array}{c}.531 \\
(.499)\end{array}$ \\
\hline Run own Business & $\begin{array}{c}.172 \\
(.378)\end{array}$ & $\begin{array}{c}.213 \\
(.410)\end{array}$ & $\begin{array}{l}.161 \\
(.368)\end{array}$ \\
\hline Computer at work & $\begin{array}{c}.786 \\
(.410)\end{array}$ & $\begin{array}{c}.838 \\
(.369)\end{array}$ & $\begin{array}{c}.772 \\
(.420)\end{array}$ \\
\hline Own comp last year & $\begin{array}{c}.751 \\
(.432)\end{array}$ & $\begin{array}{c}.839 \\
(.368)\end{array}$ & $\begin{array}{c}.728 \\
(.445)\end{array}$ \\
\hline
\end{tabular}


TABLE 2: BASIC RESULTS

\begin{tabular}{|c|c|c|c|c|}
\hline & (1) & (2) & $\begin{array}{c}(3) \\
\text { Top } 30 \text { Metro }\end{array}$ & $\begin{array}{c}(4) \\
\text { Top } 30 \text { Metro }\end{array}$ \\
\hline Method & Probit & Tobit & Probit & Tobit \\
\hline$(1+t)$ & $\begin{array}{c}.4554 \\
(.1546)\end{array}$ & $\begin{array}{l}1366.12 \\
(363.60)\end{array}$ & $\begin{array}{c}.6046 \\
(.1751)\end{array}$ & $\begin{array}{l}1287.82 \\
(477.04)\end{array}$ \\
\hline Income & $\begin{array}{l}.0005 \\
(.0001)\end{array}$ & $\begin{array}{l}1.76 \\
(.17)\end{array}$ & $\begin{array}{c}.0006 \\
(.0001)\end{array}$ & $\begin{array}{l}1.96 \\
(.22)\end{array}$ \\
\hline Education & $\begin{array}{l}.0052 \\
(.0013)\end{array}$ & $\begin{array}{l}18.25 \\
(2.94)\end{array}$ & $\begin{array}{c}.0040 \\
(.0017)\end{array}$ & $\begin{array}{l}17.73 \\
(4.14)\end{array}$ \\
\hline Age & $\begin{array}{l}-.0022 \\
(.0002)\end{array}$ & $\begin{array}{l}-5.30 \\
(.55)\end{array}$ & $\begin{array}{l}-.0023 \\
(.0003)\end{array}$ & $\begin{array}{l}-5.72 \\
(.76)\end{array}$ \\
\hline Asian & $\begin{array}{c}.0102 \\
(.0161)\end{array}$ & $\begin{array}{c}60.19 \\
(39.12)\end{array}$ & $\begin{array}{c}.0198 \\
(.0191)\end{array}$ & $\begin{array}{c}80.67 \\
(47.01)\end{array}$ \\
\hline Nonwhite minority & $\begin{array}{l}-.0068 \\
(.0091)\end{array}$ & $\begin{array}{c}-9.80 \\
(17.40)\end{array}$ & $\begin{array}{l}-.0040 \\
(.0128)\end{array}$ & $\begin{array}{c}-7.78 \\
(22.84)\end{array}$ \\
\hline Children & $\begin{array}{l}-.0378 \\
(.0059)\end{array}$ & $\begin{array}{l}-87.51 \\
(13.59)\end{array}$ & $\begin{array}{l}-.0521 \\
(.0075)\end{array}$ & $\begin{array}{l}-116.57 \\
(19.04)\end{array}$ \\
\hline Single & $\begin{array}{l}.0364 \\
(.0067)\end{array}$ & $\begin{array}{l}113.64 \\
(14.71)\end{array}$ & $\begin{array}{c}.0437 \\
(.0092)\end{array}$ & $\begin{array}{l}123.41 \\
(20.37)\end{array}$ \\
\hline Female & $\begin{array}{l}.0731 \\
(.0056)\end{array}$ & $\begin{array}{l}203.52 \\
(12.62)\end{array}$ & $\begin{array}{c}.0766 \\
(.0078)\end{array}$ & $\begin{array}{l}223.22 \\
(17.48)\end{array}$ \\
\hline Run own Business & $\begin{array}{l}.0563 \\
(.0073)\end{array}$ & $\begin{array}{l}155.06 \\
(15.16)\end{array}$ & $\begin{array}{c}.0542 \\
(.0096)\end{array}$ & $\begin{array}{l}148.32 \\
(20.75)\end{array}$ \\
\hline Computer at work & $\begin{array}{l}.0273 \\
(.0072)\end{array}$ & $\begin{array}{c}90.70 \\
(16.45)\end{array}$ & $\begin{array}{c}.0359 \\
(.0094)\end{array}$ & $\begin{array}{l}110.83 \\
(23.79)\end{array}$ \\
\hline Own comp last year & $\begin{array}{c}.0970 \\
(.0066)\end{array}$ & $\begin{array}{l}228.12 \\
(15.49)\end{array}$ & $\begin{array}{c}.0858 \\
(.0092)\end{array}$ & $\begin{array}{l}211.63 \\
(21.39)\end{array}$ \\
\hline$\sigma$ & & $\begin{array}{c}671.11 \\
(7.66)\end{array}$ & & $\begin{array}{c}703.11 \\
(10.45)\end{array}$ \\
\hline $\mathrm{N}$ & 24499 & 24697 & 13930 & 13930 \\
\hline
\end{tabular}

Notes: Standard errors in parentheses. The method of estimation is listed at the top of each column. The dependent variable in columns (1) and (3) is whether the individual reports having bought something online. The dependent variable in columns (2) and (4) is the amount that the individual has spent online as defined in the text. The sample in the last two columns is restricted to people in the top 30 largest greater metropolitan areas in the data. 
TABLE 3: RESULTS WITHIN REGIONS, STATES, AND METROPOLITAN AREAS

\begin{tabular}{|c|c|c|c|c|c|c|c|c|}
\hline & $(1)$ & $(2)$ & $(3)$ & $(4)$ & $(5)$ & $(6)$ & $(7)$ & $(8)$ \\
& & & & & & Top 4 & Top 4 \\
\hline Method & Probit & Tobit & Probit & Tobit & Probit & Tobit & Probit & Tobit \\
$(1+t)$ & .4586 & 1284.9 & 1.6041 & 4268.0 & .7097 & 1548.7 & 1.5933 & 3148.7 \\
& $(.1554)$ & $(415.9)$ & $(.6258)$ & $(1525.9)$ & $(.3059)$ & $(786.0)$ & $(.2811)$ & $(1256.5)$ \\
Demog: & 11 vars & 11 vars & 11 vars & 11 vars & 11 vars & 11 vars & 11 vars & 11 vars \\
Dums: & Region & Region & State & State & Metro & Metro & Metro & Metro \\
$\mathrm{N}$ & 24135 & 24135 & 24135 & 24135 & 24117 & 24117 & 3706 & 3706 \\
\hline
\end{tabular}

Notes: Standard errors in parentheses. The method of estimation is listed at the top of each column. The dependent variable in columns (1), (3), (5), and (7) is whether the individual reports having bought something online. The dependent variable in columns (2), (4), (6) and (8) is the amount that the individual has spent online as defined in the text. Each column includes dummy variables as indicated at the base of the column. Columns (7) and (8) restrict the sample to respondents in the New York City, Philadelphia, Boston, and Washington, D.C., areas. 
TABLE 4: ADVANCED RESULTS: CONTROLLING FOR UNOBSERVABLES

\begin{tabular}{|c|c|c|c|c|c|}
\hline & $\begin{array}{c}\text { (1) } \\
\text { Income Tax }\end{array}$ & $\begin{array}{l}\text { (2) } \\
\text { Buy Online }\end{array}$ & $\begin{array}{l}\text { (3) } \\
\text { Frequency } \\
\text { of use }\end{array}$ & $\begin{array}{c}\text { (4) } \\
\text { \# of Comps } \\
\text { (Ever) }\end{array}$ & $\begin{array}{c}\text { (5) } \\
\text { "Like } \\
\text { Technology" }\end{array}$ \\
\hline Method & Probit & Probit & OLS & OLS & OLS \\
\hline$(1+t)$ & $\begin{array}{c}.7866 \\
(.2814)\end{array}$ & $\begin{array}{c}.7338 \\
(.2705)\end{array}$ & $\begin{array}{c}.1013 \\
(7.510)\end{array}$ & $\begin{array}{l}-.8575 \\
(.8057)\end{array}$ & $\begin{array}{l}-1.626 \\
(1.500)\end{array}$ \\
\hline Freq. of Use & & $\begin{array}{c}.0086 \\
(.0003)\end{array}$ & & & \\
\hline $\mathrm{t}_{\mathrm{INC}}$ & $\begin{array}{c}.2014 \\
(.2277)\end{array}$ & & & & \\
\hline $\begin{array}{l}\text { Demographics } \\
\text { Dummies }\end{array}$ & $\begin{array}{l}11 \text { vars } \\
\text { Metro }\end{array}$ & $\begin{array}{l}11 \text { vars } \\
\text { Metro }\end{array}$ & $\begin{array}{l}11 \text { vars } \\
\text { Metro }\end{array}$ & $\begin{array}{l}11 \text { vars } \\
\text { Metro }\end{array}$ & $\begin{array}{l}11 \text { vars } \\
\text { Metro }\end{array}$ \\
\hline $\begin{array}{l}\mathrm{N} \\
\mathrm{R}^{2}\end{array}$ & $\begin{array}{c}23202 \\
--\end{array}$ & $\begin{array}{c}24117 \\
-- \\
\end{array}$ & $\begin{array}{c}24683 \\
.063 \\
\end{array}$ & $\begin{array}{c}23969 \\
.368\end{array}$ & $\begin{array}{c}24423 \\
.118\end{array}$ \\
\hline
\end{tabular}

Notes: Standard errors in parentheses. The method of estimation is listed at the top of each column. The dependent variable in columns (1) and (2) is whether the individual reports having bought something online. The dependent variable in column (3) is the frequency of going online in days per month. The dependent variable in column (4) is the number of computers the respondent reports ever having owned. The dependent variable in column (5) is the ranking from one to ten that the respondent gives to the statement "I like technology." 
TABLE 5: RETAIL, MAIL-ORDER, AND INTERNET FOR COMPUTERS

\begin{tabular}{|c|c|cc|}
\hline & $(1)$ & $(2 \mathrm{a})$ & $(2 \mathrm{~b})$ \\
& All Remote Sales & Mail-Order & Internet \\
\hline Mail \& Internet Together & & & \\
& & & \\
$(1+\mathrm{t})$ & 5.787 & 6.123 & 10.647 \\
& $(1.835)$ & $(1.994)$ & $(7.016)$ \\
& 11 vars & 11 vars & 11 vars \\
Demographics & metro & metro & metro \\
Dummies & 37994 & 37994 & 37994 \\
$\mathrm{n}$ & & & \\
\hline
\end{tabular}

Notes: Standard errors in parentheses. The sample in both regressions is restricted to computer owners. Column (1) estimates a logit model where the dependent variable is a zero if the individual bought their computer in a retail store and one if they bought it either from mail-order or online. Column (2a) and (2b) are from a multinomial logit regression where the dependent variable is zero if the individual bought their computer in a store, one if they bought through mail-order and 2 if they bought online. The coefficients on the other variables are restricted to be the same for the two alternatives to retail. 


\section{References}

Advisory Council on Intergovernmental Relations (1986), State and Local Taxation of Out-ofState Mail Order Sales, Government Printing Office, Washington, D.C.

Bailey, Joseph (1998), "Electronic Commerce: Prices and Consumer Issues for Three Products: Books, Compact Discs, and Software," Organization for Economic Cooperation and Development, OCDE/GD(98)4.

Besley, Tim and Harvey Rosen (1997), "Sales Taxes and Prices: An Empirical Analysis" Center for Economic and Policy Studies Working Paper 38.

Bourgeois, Pierre, and Luc Buchette (1997), "The Internet, Electronic Commerce, and Taxes-Some Reflections: Part 1," Canadian Tax Journal, 45, 1127-1149.

Braid, R. (1987), “The Spatial Incidence of Retail Sales Taxes,” Quarterly Journal of Economics, $102,881-891$.

Bureau of the Census (various issues), Monthly Retail Sales, Government Printing Office, Washington, D.C.

Cortlett, W. and D. Hague (1954), "Complentarity and the Excess Burden of Taxation," Review of Economic Studies 21: 21-30.

Department of Commerce (1998), The Emerging Digital Economy. (G.P.O.; Washington, D.C.).

Downes, Tom and Shane Greenstein (1998), "Universal Access and Local Commercial Internet Markets," Mimeo, Northwestern University.

Economist, The (1997a), “The Disappearing Taxpayer,” p. 15, May 31st.

Economist, The (1997b), “Taxes Slip Through the Net,” p. 22, May 31st.

Fox, William (1986), “Tax Structure and the Location of Economic Activity Along State Borders," National Tax Journal, 14, 362-374.

Fox, William and Matthew Murray (1997), “The Sales Tax and Electronic Commerce: What's New?” National Tax Journal, 50(3), 573-592.

Galbraith, John and Murray Kaiserman (1997), "Taxation, Smuggling, and Demand for Cigarettes in Canada: Evidence from Time-Series Data.” Journal of Health Economics, 16, 287-301.

Goldman Sachs, “Cyber Commerce: Internet Tsunami,” August. 
Goolsbee, Austan (1998), "Investment Tax Incentives, Prices, and The Supply Of Capital Goods," Quarterly Journal of Economics, 113(1): 121-148.

Goolsbee, Austan and Peter Klenow (1998), "Evidence on Learning and Network Externalities in the Diffusion of Home Computers," Mimeo, University of Chicago, GSB.

Goolsbee, Austan and Jonathan Zittrain (1998), “Should We Tax Internet Commerce?” Mimeo in progress, Berkman Center for Internet and Society, Harvard Law School.

Gordon, Roger (1983), “An Optimal Taxation Approach to Fiscal Federalism,” Quarterly Journal of Economics, 98, 567-586.

Gordon, Roger and Soren Nielsen (1997), "Tax Evasion in an Open Economy: Value-Added vs. Income Taxation," Journal of Public Economics, 66, 173-197.

Greenstein, Shane (1998), "Universal Service in the Digital Age: The Commercialization and Geography of U.S. Internet Access," NBER Working Paper \# 6453.

Hof, Richard (1998), “The Net is Open for Business -- Big Time,” BusinessWeek, p. 108, August, 31.

Holmes, Thomas (1998), "The Effect of State Policies on the Location of Manufacturing: Evidence from State Borders," Journal of Political Economy, 106(4) 667-705.

Horner, Frances, and Jeffrey Owens (1996), "Tax and the Web: New Technology, Old Problems," International Bureau of Fiscal Documentation Bulletin, Nov/Dec, 516-523.

Kanbur, Ravi and Michael Keen (1993), "Jeux Sans Frontieres: Tax Competition and Tax Coordination when Countries Differ in Size," American Economic Review, 83, 877-892.

Krantz, Michael (1998), “Click Till You Drop,” Time, July 20.

Mackie-Mason, Jeffrey, and Hal Varian (1995),"Pricing the Internet" in Public Access to the Internet, Brian Kahin and James Keller, eds. (MIT Press; Cambridge).

McKnight, Lee and Joeseph Bailey (1997), Internet Economics. (MIT Press, Cambridge)

McLure, Charles (1997), "Electronic Commerce, State Sales Taxation, and Intergovernmental Fiscal Relations," National Tax Journal, 50(4), 731-750.

Mikesell, John "Central Cities and Sales Tax Rate Differentials: The Border City Problem," National Tax Journal, 23(2) 206-213.

Mintz, Jack and H. Tulkens (1986), “Commodity Tax Competition Between Member States of a 
Federation: Equilibrium and Efficiency," Journal of Public Economics, 29, 133-172.

Poterba, James (1996), "Retail Price Reactions to Changes in State and Local Sales Taxes," National Tax Journal, 49, pp. 165-176.

Pouliot, Colleen (1998), Senior Vice President and General Counsel, Adobe Systems Inc., testimony before Commerce Committee, U.S. House of Representatives, July 29th.

Rand McNally (1997), Road Atlas: United States, Canada, Mexico, Deluxe 1997 edition, Rand McNally, Skokie, Illinois.

Rappaport, Neal (1994), Applied Econometric Essays on Sales Taxes and Computer Price Indices, Ph.D. Dissertation, M.I.T.

Sheppard, Doug (1998), "Representatives Of Cities, Software Publishers Square Off On Internet Taxation." State Tax Notes 15 (941).

Stephenson, Jack, and Michael Zeisser (1998), “Don't Tax the Internet--Yet," Wall Street Journal, June 6, 1998.

Trandel, Gregory (1992), "Evading the Use of Tax on Cross-Border Sales: Pricing and Welfare Effects," Journal of Public Economics, 35, 333-354.

Trandel, Gregory (1994), "Interstate Commodity Tax Differentials and the Distribution of Residents," Journal of Public Economics, 53(3), 435-457

Walsh, M, and J. Jones (1988), "More Evidence on the 'Border Tax' Effect: The Case of West Virginia," National Tax Journal, 14 362-374.

Wyden, Ron (1997), Statement on the Internet Tax Freedom Act. Homepage of the United States Senate, http://www.senate.gov/ wyden/leg/cybstate.htm, access date, November 10, 1998. 